\title{
Soil Ingestion by Mule Deer in Northcentral Colorado
}

\author{
W.J. ARTHUR, III AND A.W. ALLDREDGE
}

\section{Abstract}

Soil ingestion rates calculated from titanium concentrations in feces from mule deer (Odocoileus hemionus) feeding in a grassland-shrub community in northcentral Colorado in g/day ( $\bar{x} \pm$ $S D)$ were: spring, $29.6 \pm 20.1$; summer, $7.7 \pm 10.2$; fall, $8.8 \pm 6.5$; and winter $18.3 \pm 10.8$. Based on observations of feeding tame deer, intake in winter appeared to be primarily due to direct soil ingestion from pocket gopher (Thomomys talpoides) mounds, roads, and other areas of exposed soil. The greatest intake during spring was likely due to indirect consumption of soil adhering to ingested vegetation. Soils from locations where tame deer had consumed soil were analyzed for trace elements $(\mathrm{Ca}, \mathrm{Cu}, \mathrm{Fe}, \mathrm{Mg}$, $\mathrm{Mn}, \mathrm{P}, \mathrm{K}, \mathrm{Na}$, and $\mathrm{Zn}$ ) and compared to areas where no soil intake was observed. No significant differences $(\alpha=0.05)$ in mean levels of these elements was detected between areas. Most likely, deer at Rocky Flats were not selecting soils based strictly on mineral content, but instead were consuming soil indiscriminately. Ingested soil may provide a source of trace elements as well as a mode of entry for environmental pollutants.

Ingestion of soil and grit by both domestic and wild ruminants has been indicated as a possible source of trace elements (Healy 1968, Healy et al. 1970, Mayland et al. 1975, and Skipworth 1974) as well as a potential intake pathway for environmental pollutants (Mayland et al. 1977). In our study, which was

Arthur's present address is U.S. Department of Energy, Environmental Sciences Branch. Idaho National Engineering Laboratory. Idaho Falls, ID 83401.

Authors express appreciation to the following: W.B. Healy of the Soil Bureau, New Zealand, and H.F. Mayland of the Snake River Conservation Research Center, Idaho, for helpful suggestions; R. Keiss of the Colorado Division of Wildlife for trace element analysis on soil samples; W. Ferguson and D. Bigelow of the Colorado State University Analytical Chemistry Facility for conducting titanium analysis; G.S. Hiatt for aid in sample collection; D. Hein, for critical review of this manuscript. This research was funded through Energy Research and Development Administration Contract No. E(11-1)-

1156 with Colorado State University

Manuscript received February 27, 1978 designed to measure plutonium intake by mule deer (Odocoileus hemionus) feeding in a radioactively contaminated area at Rocky Flats Nuclear Weapons Plant, Colorado, it became necessary to quantify soil ingestion rates. Little (1976) reported that the majority of the plutonium contamination at Rocky Flats was associated with soil, and our observations of wild and tame deer during their foraging indicated that these animals consumed soil either directly (Fig. 1) or with ingested vegetation.

Healy (1968) and Mayland et al. (1975, 1977) quantified soil ingestion in cattle by measuring concentrations of a trace element, titanium, in feces, but we know of no reports quantifying soil intake in wild ruminants. We employed the titanium tracer technique, and it is the purpose of this report to describe

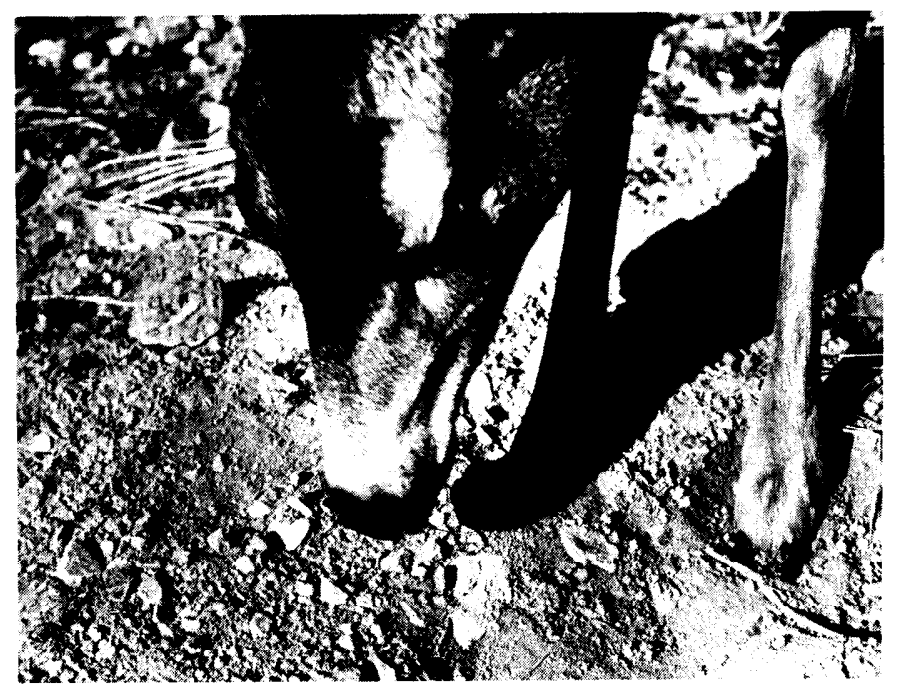

Fig. 1. Field observations of tame deer indicated that these animals consumed soil while feeding at Rocky Flats Nuclear Weapons Plant. 
our methods and to present daily soil intake rates for mule deer feeding in a grassland-shrub community during each season from December 1975 to December 1976.

\section{Study Area}

Research was conducted on property owned by the U.S. Department of Energy (DOE) surrounding the Rocky Flats Nuclear Weapons Plant $12 \mathrm{~km}$ northwest of Denver, Colorado. Portions of this property have been accidentally contaminated with plutonium (Krey and Hardy 1970; Krey and Krajewski 1972), which has led to numerous studies including our own.

Primarily a grassland, the area has a mean elevation of $1,800 \mathrm{~m}$ and is characterized by flat, wind-scoured plateaus interspersed with ravines. Vegetation communities described by Clark and Webber (1975) were dominated by moist meadows; principal species were slender wheatgrass (Agropyron trachycaulum), cheatgrass (Bromus tectorum), bluegrass (Poa spp.), and salsify (Tragopogon dubius). Upland sites were occupied by dry prairie consisting of junegrass (Koeleria gracilis), slender wheatgrass, mountain muhly (Muhlenbergia montana), needlegrass (Stipa comata), little bluestem (Schizachyrium scoparium), sage (Artemesia ludoviciana), golden aster (Heterotheca villosa), and pussytoes (Antennaria parvifolia). Strcamside vegetation occurred on approximately $5 \%$ of the study area and was dominated by shrub species: snowberry (Symphoricarpos occidentalis), plains cottonwood (Populus sargentii), willow (Salix spp.), and lead plant (Amorpha fruticosa).

Mule deer were the most conspicuous wild mammal utilizing the study area, with 90 to 100 of these animals frequently being observed on approximately $25 \mathrm{~km}^{2}$ of DOE-owned property (Hiatt 1977).

\section{Methods}

Measurement of soil ingestion using titanium as a tracer has been discussed by Healy (1968) and Mayland et al. (1975), who reported that titanium, relatively abundant in soil $(1,000$ to $3,000 \mathrm{ppm})$, is contained in amounts less than $1 \mathrm{ppm}$ in plants and is not taken up by the ruminant body (Miller et al. 1975). If these assumptions are correct, then by knowing the daily mass of fecal excretion and titanium concentrations in soil and feces, one could calculate the daily soil intake.

To measure titanium concentration in soil at Rocky Flats, five representative soil samples were collected from the upper $3 \mathrm{~cm}$ of the soil profile. Samples were oven-dried for 48 hours at $80^{\circ} \mathrm{C}$, sieved through a 2-mm mesh screen, and analyzed for titanium using a Gilford spectrophotometer at the Colorado State University Analytical Chemistry Facility. All titanium analysis conducted on soil, vegetation, feces, and tissue samples was done according to a procedure described by Bigelow (unpublished manuscript, Colorado State University Analytical Chemistry Facility 1976) and Yoe and Armstrong (1947).

Four vegetation samples were collected each season for titanium analysis and were selected as being representative of Rocky Flats vegetation consumed by deer. Vegetation composites were clipped, placed in an ultrasound bath, and washed with water. Duration of washes varied, depending upon the amount of soil associated with the plants, but in all cases washing was continued for 0.5 hour after no soil was visible in the wash pan. Samples were then oven-dried at $80^{\circ} \mathrm{C}$ for 72 hours, milled through a $2-\mathrm{mm}$ mesh screen, and analyzed. The mill was cleaned after each sample to assure that no cross-contamination of samples occurred. A two-way analysis of variance was used to test for differences in titanium concentrations among samples and seasons.

In addition to vegetation, we also conducted titanium analysis on liver, kidney, and metacarpal bone samples from two deer that were killed by automobiles in our study area. Liver and kidney samples were oven-dried for 72 hours at $105^{\circ} \mathrm{C}$ and bone samples were ashed at $600^{\circ} \mathrm{C}$ for 48 hours. Samples were ground until powdered and then analyzed.

Each season, 20, fresh, non-soil-contaminated, fecal groups were collected from the Rocky Flats property. Because we had observed fecal groups which contained pellets that appeared to be almost entirely soil, and doubted that ingested soil was uniformly distributed throughout the fecal group, we carefully collected all pellets belonging to a group. Feces were processed in the same manner as vegetation samples. Duplicate cross samples were prepared and analyzed each season to ascertain analytical error. Titanium concentrations in sample preparation solutions ranged from 0 to $4 \mathrm{ppm}(\bar{x}=2.5 \mathrm{ppm})$; therefore all tecal, vegetaion, soil and tissue samples were corrected for this potential error source.

Titanium concentrations measured in Rocky Flats vegetation were much higher than values previously reported (Healy 1968) and because of this, we corrected all titanium concentrations measured in feces for the contribution that could have come from vegetation. The following calculations made for daily soil ingestion during spring are provided to illustrate our approach:

I. $\frac{242.8 \mathrm{ppm} \text { titanium }}{\mathrm{g} \text {-feces }} \times \frac{401.3 \mathrm{~g} \text {-feces }}{\text { deer-day }}=\frac{97435.6 \mathrm{ppm} \text { titani }}{\text { deer-day }}$
II. $\frac{8.8 \mathrm{ppm} \text { titanium }}{\mathrm{g} \text {-plant }} \times \frac{1390.2 \mathrm{~g} \text {-plant }}{\text { deer-day }}=\frac{12233.8 \mathrm{ppm} \text { titan }}{\text { deer-day }}$
III. $97435.6-12233.8=\frac{85201.8 \mathrm{ppm} \text { titanium }}{\text { deer-day }}$
IV. $\frac{85201.8 \mathrm{ppm} \text { titanium }}{\text { deer-day }} \times \frac{\mathrm{g} \text {-soil }}{2880 \mathrm{ppm} \text { titanium }}=\frac{29.6 \mathrm{~g} \text {-soil }}{\text { deer-day }}$

Part I calculates the total amount of titanium from all sources that is excreted in one day. The amount of feces defecated each day was estimated by collecting complete pellet groups from the Rocky Flats area. Individual pellet group mass was multiplied by 13.2 (Smith 1964) to obtain daily fecal mass excreted. Results for spring, summer, fall, and winter were $401,527,351$, and $396 \mathrm{~g} /$ day, respectively (Arthur 1977). Analysis of variance for differences in mean weight per pellet group over seasons was not significant at the $\alpha=0.05$ level $\left(F_{3,115}=1.99\right)$.

Part 11 calculates titanium intake from vegetation, based on measured concentrations in vegetation that had been ultrasound washed. Forage intake rates of deer of $1,390 \mathrm{~g} /$ day for spring, summer and fall seasons, and 1,145 g/day for winter were obtained from Alldredge et al. (1974). Part III, above, calculates the amount of titanium in feces that came from ingestion of soil. In part IV titanium concentrations in daily fecal excretion are related to soil excretion by using measured titanium concentrations in Rocky Flats soils. If we assume that a steady state condition exists and that no titanium is being absorbed from the gut, then the amount of soil excreted each day should equal the amount of soil ingested each day.

A portion of our study involved the "bite count" technique (Wallmo and Neff 1968) for determination of food habits, and in the process of observing tame deer feeding at Rocky Flats, we noticed them consuming soil. Soil ingestion by tame deer was categorized as either attachment to plant roots, attachment to above ground plant parts, or direct intake. When ingested soil was associated with plant material, the species of plants was recorded. Specific areas where direct intake was observed were noted, and soil from these areas was collected.

In order to determine whether or not deer were selecting soil on the basis of trace element content, samples were collected from the upper $3 \mathrm{~cm}$ of soil from under vegetation litter, along roads and from pocket gopher mounds. Roads and pocket gopher mounds were areas where deer often consumed soil. Soil samples were screened through a 24-mesh screen, extracted in a $0.1 \mathrm{~N} \mathrm{HCl}$ solution for 24 hours on a shaker, and analyzed on a flame photometer for calcium, copper, iron, magnesium, manganese, phosphorus, potassium, sodium, and zinc. Mean concentrations of these elements were log normalized, plotted against collection areas and analyzed for consistency among peaks at specitic areas. 


\section{Results}

Titanium concentrations in soil ranged from 2,600 to 3,100 $\operatorname{ppm}(\bar{x}=2,880, S D=192 \mathrm{ppm})$, with the highest value coming from a sample collected from a pocket gopher mound. The mean titanium concentration in vegetation was $17.3 \mathrm{ppm}(S D=8.1$ $\mathrm{ppm}$ ) with a range of values of $8.8 \mathrm{ppm}$ in spring to $21.8 \mathrm{ppm}$ during the fall season. Analysis of variance revealed no significant differences $(\alpha=0.05)$ between concentrations in vegetation among seasons or areas. Titanium concentrations in mule deer bone samples were less that $1 \mathrm{ppm}$, while kidney samples had a mean concentration of $20.5 \mathrm{ppm}(S D=6.5 \mathrm{ppm})$, and liver samples had a mean of $22.0 \mathrm{ppm}(S D=2.0 \mathrm{ppm})$. Table 1 lists mean titanium concentrations in mule deer feces for each season. The highest concentration occurred in spring $(x=$ $242.8 \mathrm{ppm})$ and the lowest in summer $(x=87.2 \mathrm{ppm})$. Analysis of variance was significant $\left(F_{3, i t}=9.69\right)$ for differences in seasonal mean concentrations of titanium. Duncan's test (Duncan 1965) showed that the spring mean was significantly greater than the summer and fall means, but not the winter mean. $T$-tests conducted on titanium concentrations in fecal samples from sampling areas at Rocky Flats were not significant $(\alpha=0.05)$ indicating no area differnces. Blind duplicate error for 20 fecal samples averaged $19.7 \%(S D=20.9 \%)$ and was believed to be associated with our method of dividing samples.

Table 1. Seasonal titanium concentrations in mule deer feces at Rocky Flats Nuclear Weapons Plant, Colorado, 1976.

\begin{tabular}{|c|c|c|c|c|}
\hline & $\begin{array}{l}\text { Winter } \\
(75-76)\end{array}$ & $\begin{array}{l}\text { Spring } \\
\text { (76) }\end{array}$ & $\begin{array}{c}\text { Summer } \\
(76)\end{array}$ & $\begin{array}{l}\text { Fall } \\
(76)\end{array}$ \\
\hline $\bar{x}(\mathrm{ppm}$ titanium) & 195.7 & 242.8 & 87.2 & 155.1 \\
\hline$S D(\mathrm{ppm}$ titanium $)$ & 78.5 & 144.3 & 55.7 & 59.4 \\
\hline Coefficient of variation $(\%)$ & 40.1 & 59.4 & 63.9 & 38.3 \\
\hline Range (ppm titanium) & $89-375$ & $57-530$ & $45-250$ & $24-250$ \\
\hline Sample size & 18 & 20 & 20 & 20 \\
\hline
\end{tabular}

Mean daily rates of soil intake were calculated for each -season by correcting for titanium concentrations in vegetation (Table 2). Soil ingestion was highest during winter and spring with a daily intake of 18.3 and $29.6 \mathrm{~g}$ of soil, respectively. Analysis of variance showed significant difference $(\alpha=0.05)$ in mean daily soil intake between seasons. Duncan's test indicated that spring mean was significantly greater than those for fall and summer, but not for winter.

Results of trace element analysis from Rocky Flats soils are presented in Table 3. A log-transformation of mean element concentrations and a $t$-test conducted on means between areas where soil was seen ingested versus areas where none was
Table 2. Seasonal soil ingestion rates for mule deer at Rocky Flats Nuclear Weapons Plant, Colorado, 1976.

\begin{tabular}{|c|c|c|c|c|}
\hline & $\begin{array}{c}\text { Winter } \\
(75-76)\end{array}$ & $\begin{array}{l}\text { Spring } \\
(76)\end{array}$ & $\begin{array}{l}\text { Summer } \\
(76)\end{array}$ & $\begin{array}{l}\text { Fall } \\
(76)\end{array}$ \\
\hline $\begin{array}{l}\bar{x} \text { (grams soil per deer } \\
\text { per day }\end{array}$ & 18.3 & 29.6 & 7.7 & 8.8 \\
\hline $\begin{array}{l}S D \text { (grams soil per deer } \\
\text { per day) }\end{array}$ & 10.8 & 20.1 & 10.2 & 6.5 \\
\hline $\begin{array}{l}\text { Coefficient of } \\
\text { variation }(\%)\end{array}$ & 59.0 & 67.9 & 132.5 & 73.9 \\
\hline Range & $3.7-43.0$ & $3.7-69.6$ & $0.0-37.6$ & $0.0-20.0$ \\
\hline Sample size & 18 & 20 & 20 & 20 \\
\hline
\end{tabular}

observed ingested indicated that there were no significant differences $(\alpha=0.05)$ in trace element concentrations among any samples.

\section{Discussion}

Our measured titanium concentrations in soil fell within the ranges reported by Healy (1968). Small variations of titanium concentrations in soils were found to exist locally in our study area, but a greater variability might be expected over wider geographical areas because of varying geologic conditions.

Titanium concentrations in vegetation collected in our study were higher than those cited in the literature (Healy 1968: 1 ppm). Either Rocky Flats' vegetation contained more titanium than was reported in other studies (Healy 1968; Mayland et al. $1975,1977)$ or there were differences in analytical capabilities. Our wet chemistry method had a lower detection limit of approximately $10 \mathrm{ppm}$ as compared to a lower limit of $50 \mathrm{ppm}$ for the X-ray fluorescence techniques used in other work (H.F. Mayland, personal communication 1977). Another possibility is that vegetation samples had soil particles adhered to their surfaces. Using our measured titanium concentrations in soil, approximately $120 \mathrm{mg}$ of soil would need to be associated with a $20-\mathrm{g}$ vegetation sample to result in a concentration of $17 \mathrm{ppm}$ titanium. A quantity this large should have been seen, and it is doubtful that ultrasound washing would have failed to remove that much soil from plant samples. Therefore, we believe that titanium concentrations we measured were the result of titanium in vegetation, and improved analytical sensitivity may best explain our higher values.

We also measured higher titanium concentrations in mule deer liver and kidney than had been previously reported for terrestrial mammals (Bowen 1966). Because our samples came from deer that had been killed by automobiles, these samples could have been contaminated with soil, resulting in the higher

Table 3. Trace element concentrations (ppm) in upper $3 \mathrm{~cm}$ of soils collected under vegetation, from roads, streambanks, and gopher mounds at Rocky Flats Nuclear Weapons Plant, Colorado.

\begin{tabular}{|c|c|c|c|c|c|c|c|c|c|c|}
\hline Source & & K & $\mathrm{Cu}$ & $\mathrm{Fe}$ & $\mathrm{Zn}$ & $\mathrm{Mg}$ & $\mathrm{Na}$ & $\mathrm{Ca}$ & $\mathbf{P}$ & $\mathrm{Mn}$ \\
\hline Under vegetation & $\bar{x}$ & 537.5 & 11.3 & 575 & 17.5 & 487.5 & 42.5 & 3350 & 1500 & 287.5 \\
\hline$(n=2)$ & $S D$ & 62.5 & 1.9 & 75 & 0.0 & 37.5 & 5.0 & 250 & 250 & 12.5 \\
\hline Road & $\bar{x}$ & 433.3 & 14.8 & 633 & 10.0 & 916.7 & 68.3 & 6100 & 833 & 233.7 \\
\hline$(n=3)$ & $S D$ & 77.3 & 9.4 & 103 & 2.0 & 117.9 & 30.6 & 2844 & 312 & 35.6 \\
\hline Streambank & $\bar{x}$ & 312.5 & 8.5 & 950 & 10.0 & 700 & 70.0 & 8200 & 1000 & 156.5 \\
\hline$(n=2)$ & $S D$ & 12.5 & 1.6 & 200 & 2.5 & 500 & 37.5 & 4100 & 250 & 18.5 \\
\hline Gopher mound & $\bar{x}$ & 496.4 & 7.0 & 561 & 11.4 & 582 & 47.9 & 3257 & 1071 & 264.4 \\
\hline$(n=7)$ & $S D$ & 49.0 & 1.1 & 122 & 4.6 & 96 & 14.8 & 420 & 319 & 40.5 \\
\hline Total & $\bar{x}$ & 462.5 & 9.5 & 634 & 11.8 & 657 & 54.6 & 4586 & 1071 & 245.7 \\
\hline$(n=14)$ & $S D$ & 88.5 & 5.5 & 184 & 4.3 & 255 & 25.1 & 2773 & 359 & 52.5 \\
\hline
\end{tabular}


titanium values. Greater analytical sensitivity could also explain our higher values. Miller et al. (1975) reported that titanium absorption in domcstic sheep did not exceed $0.5 \%$ and concluded that titanium could be used as a satisfactory index for soil ingestion by ruminants. We assumed titanium absorption by mule deer was negligible.

The largest daily intake of soil for mule deer feeding at Rocky Flats occurred during the winter and spring seasons, with spring being significantly greater than the other seasons. Observations made on tame deer feeding at Rocky Flats during the winter season (Table 4) indicated that the main portion of their soil intake was taken directly from pocket gopher mounds, roads and other areas where soil was exposed. In spring the high soil consumption of $29.6 \mathrm{~g} /$ day may have been primarily due to soil attached to roots of low growing grasses and forbs (cheatgrass, bluegrass, pasture sage, filaree (Erodium cicutarium), and musineon (Musineon divarcatum), that made up a large portion of deer diets at this time (Arthur 1977). Observations made on tame deer (Table 4) indicated that the majority of their soil intake came about in this manner, which is in agreement with the findings of Mayland et al. (1975) for cattle on a grassland range in southern Idaho. Skipworth (1974) found the largest grit intake by bighorn shecp (Ovis canadensis) occurred in spring, but he did not indicate how this intake came about.

Table 4. Frequency of soil ingestion for tame mule deer observed during food habits trails ${ }^{1}$ at Rocky Flats Nuclear Weapons Plant, Colorado.

\begin{tabular}{lrrrr}
\hline & \multicolumn{4}{c}{ Number of soil ingestion observations } \\
\cline { 2 - 6 } Source & Spring & Summer & Fall & Winter \\
\hline Root of grass, forb & 27 & 27 & 34 & 59 \\
$\begin{array}{l}\text { Above-ground plant } \\
\quad \text { portion }\end{array}$ & 1 & 2 & 0 & 10 \\
$\begin{array}{l}\text { Direct soil } \\
\text { Gopher mound }\end{array}$ & 11 & 19 & 15 & 27 \\
$\begin{array}{l}\text { Road } \\
\text { Total number of }\end{array}$ & 5 & 0 & 8 & 7 \\
$\quad$ times soil ingested & 1 & 2 & 2 & 5 \\
$\begin{array}{l}\text { Percent of food trials } \\
\quad \text { where soil ingested }\end{array}$ & 45 & 50 & 59 & 108 \\
$\begin{array}{l}\text { Mean number of soil } \\
\quad \text { ingestions per food }\end{array}$ & 50.0 & 58.1 & 61.2 & 54.2 \\
$\quad$ trial & & & & \\
\hline
\end{tabular}

A food haibts trial consisted of a period of time, usually I to 3 hours when deer were allowed of forage freely over the study area.

During summer and fall months, soil consumption declined sharply to 7.7 and $8.8 \mathrm{~g}$ per day, respectively. Plants in the growing state are higher in trace elements $(\mathrm{Cu}, \mathrm{Fe}, \mathrm{K}, \mathrm{Mg}, \mathrm{P}$, $\mathrm{Se}$, and $\mathrm{Zn}$; Keiss 1977) and animals may receive adequate trace elements from forage during these periods. For our tame deer it appeared that soil consumption during these seasons was due to material adhering to above-ground plant parts, and other incidental intake while foraging (Table 4).

While data in Table 2 came from analysis of fecal material from resident wild deer at Rocky Flats and should be representative of their soil intake, data presented in Table 4 were obtained from observations on our tame deer during food habits trials at Rocky Flats. We present these data as an indication of sources of soil ingestion by deer. In addition, the frequency of soil ingestion events observed in tame animals correlates with seasonal fluctuations in calculated soil intake rates for resident wild deer. The manner in which wild and tame deer ingest soil may be similar, but we would not actually expect that the frequency of direct soil ingestion would be similar in these animals. When tame deer were not being used at Rocky Flats, they were maintained in a facility at Fort Collins, Colorado, where they were provided with a commercial ration that was believed to contain adequate amounts of trace elements. Therefore, during the brief periods ( 5 to 8 days) when these animals were feeding at Rocky Flats they likely would not be stimulated to seek additional trace elements that may have been lacking in vegetation. Regretfully, we have no data on trace elements in vegetation at Rocky Flats.

Comparison of trace element content in soils collected from areas where tame deer ingested soil to areas where no soil intake was observed indicated no significant differences in elemental concentrations. If deer were selectively ingesting soil, trace element content does not appear to be the criteria of selection. However, we suspected that these animals were probably eating soil as a source of trace elements, and thus concluded that mule deer at Rocky Flats probably did not select soil, but consumed it indiscriminately from areas where it was exposed. To our knowledge, there are no natural mineral licks in the area.

Soil intake rates measured for mule deer in this study ranged from 0.6 to 2.1 percent of the weight of their total daily dry matter intake. Healy et al. (1970) reported that dairy cattle in New Zealand consumed as much as $450 \mathrm{~kg}$ per year, which was approximately $2 \%$ of their dry matter intake over the year; and Mayland et al. (1977) estimated that cattle feeding on an Idaho range in June consunied $0.73 \mathrm{~kg}$ of soil per day, which was approximately $7 \%$ of their daily dry matter intake. These and other investigators (Skipworth 1974) have suggested that foraging ruminants may consume soils as a source of trace elements lacking in vegetation.

\section{Conclusions}

Soil intake rates in grams per day for free-ranging, mule deer feeding at Rocky Flats, Colorado were $(x \pm S D)$ : spring, 29.6 \pm 20.1 ; summer, $7.7 \pm 10.2$; fall, $8.8 \pm 6.5$; and winter, $18.3 \pm$ 10.8. While we did not have data to indicate reasons for soil consumption, intake patterns measured in wild deer and observed in tame deer were inversely correlated with reported trace element concentrations in vegetation. Trace element analysis conducted on soil samples from out study area indicated that deer were probably not selecting specific soil for any trace elements in our analysis.

Observations on tame deer feeding at Rocky Flats indicated that deer may consume soil directly, consume it in association with plant roots, or take it in indirectly with above-ground portions of plants. The manner in which sol is ingested appears to be related to season of the year and species of plants in the deer diet. The greatest soil ingestion rate in spring was 29.6 $\mathrm{g} /$ day, and based on observations of tame deer the principal mode of entry was soil associated with plant roots. The second largest intake rate, $18.3 \mathrm{~g} /$ day in winter, may have come primarily from direct ingestion of soil. Low intake rates of 8.8 $\mathrm{g} /$ day and $7.7 \mathrm{~g} /$ day in fall and summer likely arose from ingestion of soil attached to above-ground plant parts.

While ingestion of soil may be an important source of trace elements for mule deer, at Rocky Flats Nuclear Weapons Plant, where soils contain measurablc amounts of plutonium, the intake of even small quantities of soil can result in the animal's consuming measurable amounts of this radioactive contaminant. The intake and subsequent fate of ingested plutonium by mule deer at Rocky Flats will be the subject of future reports. We recommend that future studies attempting to quantify soil 
ingestion using the titanium tracer technique should examine titanium in vegetation and correct for these concentrations.

\section{Literature Cited}

Alldredge, A.W., J.F. Lipscomb, and F.W. Whicker. 1974. Forage intake rates of mule deer estimated with fallout Cesium-137. J. Wildl. Manage. 38:508-516.

Arthur, W.J. III. 1977. Plutonium intake by mule deer at Rocky Flats, Colorado. MS Thesis, Colorado State Univ., Fort Collins. 123 p.

Bowen, H.J.M. 1966. Trace Elements in Biochemistry. Academic Press. New York. 241 p.

Clark, S., and P.J. Webber. 1975. Brief descriptions of the vegetation units recognized on the Rocky Flats map. Inst. of Arct. and Alpine Res., and Dep. of Environ., Pop., and Organ. Biol., Univ. of Colorado, Boulder. 18 p. Duncan, D.B. 1955. Multiple range and multiple f tests. Biometrics 11:1-42. Healy, W.B. 1968. Ingestion of soil by dairy cows. New Zealand J. Agr. Res. 11:487-499.

Healy, W.B., W.J. McCabe, and G.F. Wilson. 1970. Ingested soil as a source of microelements for grazing animals. New Zealand J. Agr. Res. 13:503-521

Hiatt, G.S. 1977. Plutonium dispersal by mule deer at Rocky Flats, Colorado. MS Thesis. Colorado State, Fort Collins. 143 p.

Keiss, R.E. 1977. Evaluation of the nutritonal requirements of bighorn sheep. Colorado Div. Wildl. P-R Proj. Rep. W-41-R-26. pp: 1-56.
Krey, P.W., and E.P. Hardy. 1970. Plutonium in soil around the Rocky Flats Plant. USAEC Rep. HASL-235. 44 p.

Krey, P.W., and B.T. Krajewski. 1972. Plutonium isotopic ratios at Rocky Flats. USAEC Rep. HASL-249. p: 67-94.

Little, C.A. 1976. Plutonium in a grassland ecosystem. PhD Thesis, Colorado State Univ., Fort Collins. $170 \mathrm{p}$

Mayland, H.F., A.R. Florence, R.C. Rosenau, V.A. Lazar, and H.A. Turner. 1975. Soil ingestion by cattle on semiarid range as reflected by titanium analysis of feces. J. Range Manage. 28:448-452.

Mayland, H.F., G.E. Shewmaker, and R.C. Bull. 1977. Soil ingestion by cattle grazing crested wheatgrass. J. Range Manage. 30:264-265.

Miller, J.K., F.C. Maasen, and S.L. Hansard. 1975. Titanium- 44 metabolism in ruminants. J. Anim. Sci. 42:279. (Abstr.)

Smith, A.D. 1964. Defecation rates of mule deer. J. Wildl. Manage. 28:435-444.

Skipworth, J.P. 1974. Ingestion of grit by bighorn sheep. J. Wildl. Manage 38:880-883.

Wallmo, O.C., and D.J. Neff, 1968. Direct observation of tame deer to measure their consumption of natural forage. P. 105-110. In: Range Wildlife Habitat Evaluation U.S. Dep. Agric. Misc. Publ. 1147, 220 p.

Yoe, J.H., and A.R. Armstrong. 1947. Colormetric determination of titanium with disodium-1, 2-dihydroxybenzene-3, 5-disulfonate. Anal. Chem. 19:100-102. 